\title{
William Penn Clarke and the Know Nothing Movement: A Document
}

\author{
INTRODUCED AND ANNOTATED BY \\ TYLER ANBINDER
}

\section{INTRODUCTION}

One of the strangest stories in American political history is that of the Know Nothing party. Growing out of the Order of the Star Spangled Banner, a secretive fraternal group that sought to curtail the political power of immigrants and Catholics, the Know Nothings burst suddenly upon the political scene in 1854 . By the end of 1855 they had elected eight governors, more than one hundred congressmen, and the mayors of Boston, Philadelphia, Chicago, and San Francisco. Yet their 1856 presidential candidate, Millard Fillmore, carried only a single state, and two years later the Know Nothings had all but vanished.

Historians today know relatively little about the inner workings of the Know Nothing party. Following the strictures of secrecy imposed upon its members, most of the Know Nothings' leaders burned their correspondence, and none published reminiscences similar to those of their Republican and Democratic counterparts. A document found recently in the North Carolina State Library in Raleigh sheds a bit of light on

Editor's note: Thanks to Michael Hill, researcher, Division of Archives and History, North Carolina Department of Cultural Resources, for bringing this document to our attention, transcribing it, providing a draft of an introduction describing its provenance and context, and arranging for its transfer to the State Historical Society of Iowa, Iowa City.

THE ANNALS OF IOWA 53 (Winter 1994). CThe State Historical Society of Iowa, 1994. 
the Know Nothings' rise and fall. Inserted at the beginning of the library's copy of Ward Lamon's Life of Abraham Lincoln is a five-page, handwritten document contesting Lamon's account of the Know Nothing and Republican national conventions of February $1856 .{ }^{1}$ The document was written by Iowa Know Nothing and Republican William Penn Clarke based on his recollections of his role in those conventions.

BORN IN BALTIMORE on October 1, 1817, Clarke spent most of his youth in southeastern Pennsylvania, where he learned the printer's trade. He was also an active Methodist. Deciding to seek his fortune in the West, Clarke worked for a time in Pittsburgh, Wheeling, Cincinnati, and Logan, Ohio, before he finally settled in 1844 in Iowa City. There he edited the Whig Iowa Standard, although he also studied law in his spare time. He was soon admitted to the bar, and by the early 1850 s he frequently tried cases before the Iowa Supreme Court. From 1855 to 1859 he served as the Iowa Supreme Court Reporter, compiling the first volumes of Iowa Reports. ${ }^{2}$

Meanwhile, Clarke became involved in politics. Although he had been an active Whig during his newspaper days (serving on the territory's Whig central committee), he left the party when it refused to endorse the Wilmot Proviso and instead nominated the slaveholder Zachary Taylor for president. Clarke immediately became a leader of Iowa's Free Soil party, acting as one of its presidential electors in 1848, and running two years later as its candidate for governor. He was also a Free Soil candidate for Congress in 1852. When the Know Nothings organized in Iowa in the summer of 1854, Clarke, like many frustrated Free Soilers, joined the secret order. Although his correspondence at the State Historical Society of Iowa in Des Moines indicates that he took an active role in the party's Iowa activities, it was not until he attended the Know Nothings' presidential nominating con-

1. The book, with Clarke's comments, has since been donated to the State Historical Society of Iowa, Iowa City.

2. Erik McKinkey Eriksson, "William Penn Clarke," Iowa Journal of History and Politics 25 (1927), 3-11. 
vention at Philadelphia in February 1856 that Clarke's prominent position in the party became publicly known. ${ }^{3}$

In order to understand the significance of Clarke's critique of Lamon, it is useful to recall the Know Nothings' exploits in the period before Clarke attended their presidential nominating convention. After their initial successes, the Know Nothings attempted to increase their appeal by converting their network of lodges into a conventional political organization, which they christened the "American party." Many observers predicted that the Know Nothings would soon control national politics and elect the next president. After all, no new political movement in American history had ever enjoyed such overwhelming success so quickly. Their victories had resulted to a large extent from the appeal of their multifaceted agenda. In addition to seeking to curtail the political power of immigrants and Catholics, Know Nothings also endorsed temperance legislation. Furthermore, Know Nothings in the North (where they achieved nearly all their early victories) worked to prevent the extension of slavery as well. Although some sought to achieve this goal by opposing the admission of additional slave states, most Know Nothings favored restoration of the Missouri Compromise instead. ${ }^{4}$ Still others joined the Know Nothings as "a half-way-house-a stopping place on the road" until a more satisfactory political organization-ultimately the Republican party-could be formed. ${ }^{5}$ This varied agenda enabled the Know Nothings to attract many more members than had previous nativist parties stressing anti-immigrant sentiment alone.

3. Eriksson, "William Penn Clarke," 38-39; Robert R. Dykstra, Bright Radical Star: Black Freedom and White Supremacy on the Hawkeye Frontier (Cambridge, MA, 1993), 81. For the Know Nothing party's founding in Iowa, see Thomas R. Whitney, A Defence of the American Policy (New York, 1856), 284; and Ronald F. Matthias, "The Know Nothing Movement in Iowa" (Ph.D. diss., University of Chicago, 1965), 9.

4. Some joined the Know Nothings hoping that their nativist agenda would help distract attention from the slavery issue, but these members made up a small minority of the organization until late 1856.

5. Henry S. Randall to D. Gilpin, 10 June 1856, filed with Gilpin to James Buchanan, 27 June 1856, Buchanan Papers, Historical Society of Pennsylvania, Philadelphia. 
As the Know Nothings spread south, however, their southern members insisted that the party must end all discussion of slavery if it hoped to carry enough states in that region to win the presidency. At their 1855 convention in Philadelphia, the southerners combined with a few conservative northerners to force through a platform stating that the party accepted the Kansas-Nebraska Act as "a final and conclusive settlement" of the slavery extension issue. This convinced many northerners that the Know Nothings would be no more of an antislavery organization than the Whigs or Democrats, and these frustrated voters then turned to the new Republican party. Others, especially those who believed that a party that combined antislavery with temperance and nativism had a better chance to carry elections than one stressing the slavery issue alone, hoped to change the platform when the Know Nothings convened to nominate a president in Philadelphia in February 1856. If these northerners succeeded, the Know Nothings would still have a realistic chance of winning the White House. If they failed, the flow of northern Know Nothings into the Republican ranks would catapult the antislavery organization past the Know Nothings as the primary challenger to the Democrats.

That was the situation as Clarke braved the snowy February weather to attend the Republican convention in Pittsburgh. He had apparently been one of those who had joined the Know Nothings as a "half-way house," for he never seems to have thought of the Know Nothings as the ideal means of combating the Slave Power. That stance was reflected in his intention to attend the Republican convention while skipping the Know Nothing gathering in Philadelphia, even though the Republican gathering was merely an organizational meeting with no pressing business before it. In contrast, Iowa would lose one-third of its allotment of delegates in the Know Nothing convention if Clarke failed to attend.

Clarke's recollection of his activities that February is significant for a number of reasons. First, it provides insight into the efforts made by Republicans to destroy the Know Nothing party. Clarke, who had not planned to attend the Know Nothings' 1856 presidential nominating convention in Philadelphia, changed his mind when fellow Republicans such as 
Horace Greeley urged him to go and stage a walkout that would speed the disintegration of the nativist organization. Clarke's revelation is not the first evidence we have of such efforts. Massachusetts Republican Samuel Bowles had helped foment discord at the Know Nothings' previous national convention, and Ohio Know Nothing president Thomas Spooner's cooperation with the Republicans had nearly caused the Know Nothings' 1856 convention to break up before Clarke arrived. Yet Clarke's recollections demonstrate that these other efforts at sabotage were not isolated incidents, but part of a concerted and wide-ranging effort by Republicans to use every means at their disposal to destroy their Know Nothing rivals. ${ }^{6}$

Clarke's memoir is also important because it adds to the growing evidence suggesting that many Americans joined the Know Nothings for reasons other than hatred of Catholics and immigrants. Clarke notes that "many joined this party from various motives, other than opposition to foreigners," and cites his desire "to divide and disrupt the Democratic Party" as the "motive which induced me to become a KnowNothing." Clarke hoped that the Know Nothings would attract enough Democrats to break that party's grip on the state's elective offices. Some voters felt guilty or embarrassed when they joined the Know Nothings for such a purpose. A Massachusetts minister who had apparently joined the Know Nothings for the same reason as Clarke apologized meekly to Charles Sumner afterward that he had done so "because I thought it would help the Anti-Slavery cause." A New Haven editor likewise confessed to his readers that he "fell into the American movement with tens of thousands of others, who found it right on slavery and right on temperance. The end is the defeat of the rum and Nebraska forces." 7

6. For Bowles, see William E. Gienapp, The Origins of the Republican Party, 1852-1856 (New York, 1987), 182-87. For Spooner, see Tyler Anbinder, Nativism and Slavery: The Northern Know Nothings and the Politics of the 1850s (New York, 1992), 208-9.

7. William C. Whitcomb to Charles Sumner, 16 January 1855, Sumner Papers, Harvard University, Cambridge, MA; New Haven Palladium, 4 April 1855. 
Free Soilers such as Clarke most often joined the Know Nothing party in northern states dominated by the Democratic party. The Know Nothing ranks in Maine, New Hampshire, and Indiana were filled with men who, like Clarke, seemed more concerned with defeating the Democrats than persecuting immigrants or Catholics. Yet one should not infer from this that immigrants and Catholics did not concern the Know Nothings. Nearly all Know Nothings believed that Catholicism was a misguided and dangerous religion and thought that the political power of its adherents (and of immigrants generally) ought to be curtailed. But the belief that the Know Nothings would provide a means to dislodge entrenched prosouthern politicians won the Know Nothings many recruits, including Clarke, who otherwise probably would not have joined a nativist party. That success helped transform the Know Nothings from a small fraternal order into a political organization of national importance.

Finally, something should be said about the work to which Clarke was replying. Ward Hill Lamon was a Virginian who had ridden the central Illinois legal circuit with Lincoln in the early days of Lincoln's legal career. Lamon served as marshal of the District of Columbia during Lincoln's presidency and afterwards practiced law in partnership with the Democratic former Attorney General Jeremiah S. Black. Lamon decided to write a biography of Lincoln, hired Black's son Chauncey to ghostwrite it, and purchased the papers of Lincoln's law partner William Herndon for use as documentation. In consultation with Herndon, whose jealousy of Lincoln became obsessive after the president's death, Black (himself no admirer of Lincoln) created a vituperative, gossipy manuscript containing a variety of scandalous charges, among them the allegations that Lincoln was an atheist and that he was conceived out of wedlock. Although Lamon deleted some of the more ridiculous portions of the manuscript, as published it was still an outrageous and overwhelmingly negative portrait. Consequently, it received scathing reviews when published in 1872 and sold very poorly. Newspapers across the country carried letters describing the book's numerous errors, and it was probably in this desire to set the record straight that Clarke penned 
his response to Lamon's work. ${ }^{8}$ The passage that provoked Clarke's ire follows: ${ }^{9}$

The American or Know-Nothing party-corrupt, hideous, and delusive, but still powerful-had adopted the old Whig platform on the several slavery questions, and planted itself decisively against the agitations of the Anti-Nebraska men and the Republicans. A "National Council" had taken this position for it the year previous, in terms beside which the resolutions of the Whigs and Democrats in 1852 were mild and inexpressive. Something, therefore, must be done to get this great organization out of the way, or to put its machinery under "Republican" control. We have seen a party of gentlemen from Chicago proposing to go into the lodges, and "rule them for freedom."10 Mr. Herndon and Mr. Lincoln rejected the plot with lofty indignation; but a section of the Free-Soil politicians were by no means so fastidious. They were for the most part bad, insincere, trading men, with whom the profession of principles of any kind was merely a convenient disguise, and who could be attached to no party, except from motives of self-interest. As yet, they were not quite certain whether it were possible to raise more hatred in the Northern mind against foreigners and Catholics than against slaveholders; and they prudently determined to be in a situation to try either. Accordingly, they went into the lodges, took the oaths, swore to stand by the platform of the "National Council" of 1855, and were perfectly ready to do that, or to betray the organization to the Republicans, as the prospect seemed good or bad. Believing the latter scheme to be the best, upon deliberation, they carried it out as far as in them lay, and then told the old, grim, honest, antislavery men,

8. David Donald, Lincoln's Herndon (New York, 1948), 250-55, 266-70. 9. Ward H. Lamon, The Life of Abraham Lincoln; From His Birth to his Inauguration as President (Boston, 1872), 378-79.

10. The "party of gentlemen" Lamon refers to was a secret fraternal order called the "Know Somethings." In some locales, Know Somethings set up lodges that operated as alternatives to the Know Nothing organization. These lodges admitted Protestant immigrants and openly stressed the slavery issue as much as anti-Catholicism. In other places, the Know Somethings sought to infiltrate the Know Nothing lodges and destroy them from within by proposing strong antislavery stances that would inevitably fail and thus disillusion free-soil Know Nothings. In either case, the goal was to push free-soilers out of the Know Nothing organization and into the Republican party. See Anbinder, Nativism and Slavery, 163-64. 
with whom they again sought association, that they had joined the Know-Nothings, and sworn irrevocable oaths to proscribe foreigners and Catholics, solely that they might rule the order "for freedom;" and, the Republicans standing in much need of aid just then, the excuse was considered very good. But it was too shameless a business for Lincoln and Herndon; and they most righteously despised it.

In February, 1856, the Republicans held what Mr. Greeley styles their "first National Convention," at Pittsburg; but they made no nominations there. At the same time, a KnowNothing American "National Council" was sitting at Philadelphia (to be followed by a nominating convention); and the Republicans at Pittsburg had not adjourned before they got news by telegraph, that the patriots who had entered the lodges on false pretences were achieving a great success: the American party was disintegrating, and a great section of it falling away to the Republicans. ${ }^{11} \mathrm{~A}$ most wonderful political feat had been performed, and the way was now apparently clear for a union of the all-formidable anti-Democratic elements in the Presidential canvass.

And here is Clarke's critique of Lamon. Notes have been added to correct Clarke's factual mistakes and to provide background concerning the events and people mentioned therein. His first sentence refers to Lamon's description of the first Republican convention as having taken place in 1856.

\section{WILLIAM PENN CLARKE'S COMMENTS}

This is erroneous. The convention at Pittsburg, at which the Republican Party was organized as a National party, was held in 1854 , not in $1856 .{ }^{12}$ I was myself a member of that Con-

11. The telegram Lamon refers to, sent by Ohio Know Nothing President Thomas Spooner, altered the course of the Know Nothing convention. Although Spooner may not have joined the Know Nothing party under "false pretences," he (like Clarke) attended the convention primarily for the purpose of disrupting it. Thus Lamon's statement is essentially accurate. See Anbinder, Nativism and Slavery, 208-9.

12. Actually, Lamon was right concerning the date of the convention, which assembled on February 22, 1856, at Lafayette Hall in Pittsburgh. 


\section{$379 \quad 1$}

This is ersoneows. The Convention Pita. bung which the Republizen Pritg was ongentis jed ar a hationel party, was hele in 1854 , net

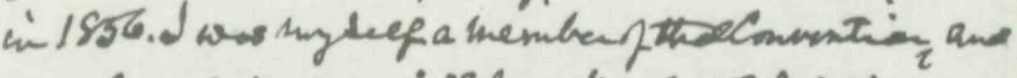

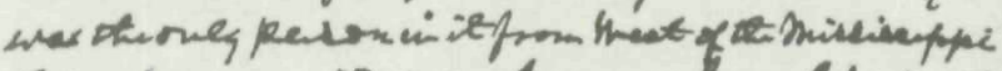

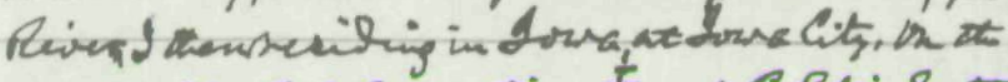

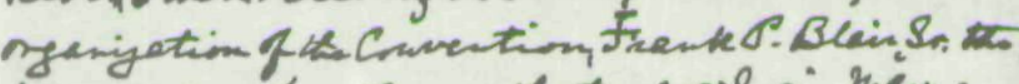

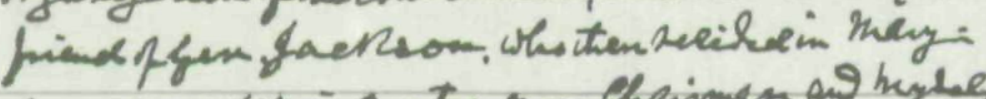

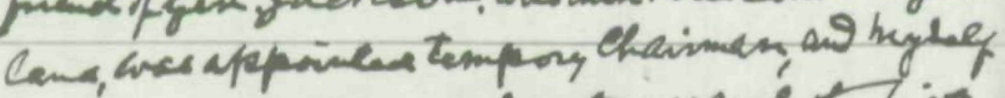

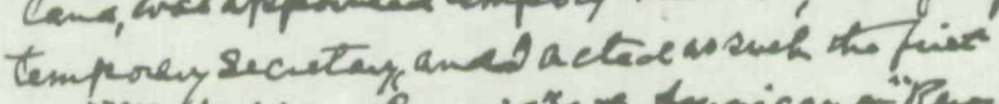

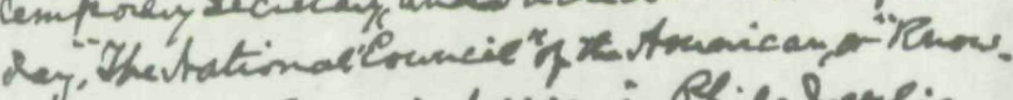

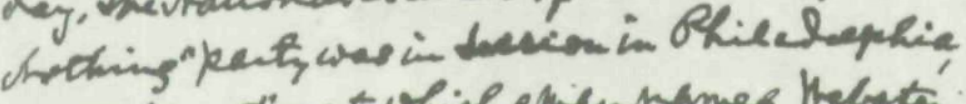

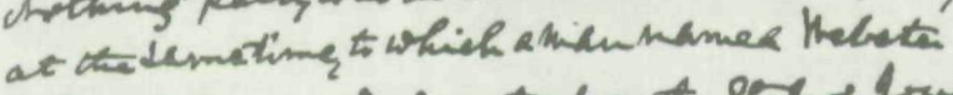

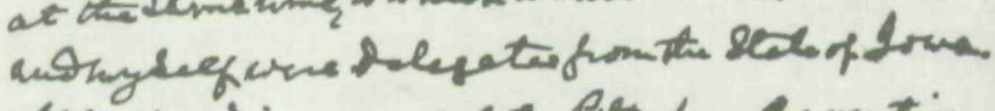

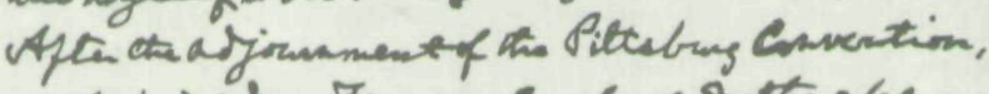

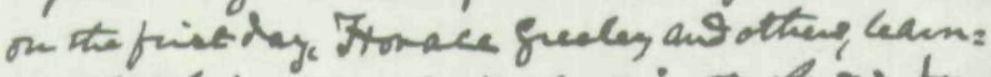

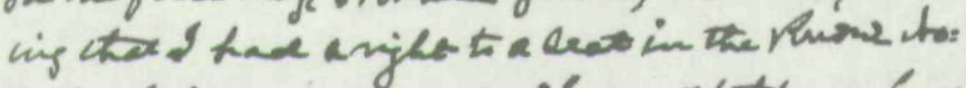
thing bal, and tee purblevy platfoum had

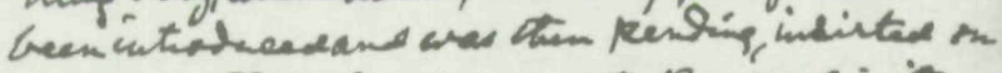

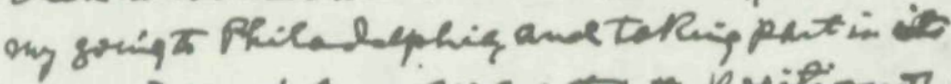

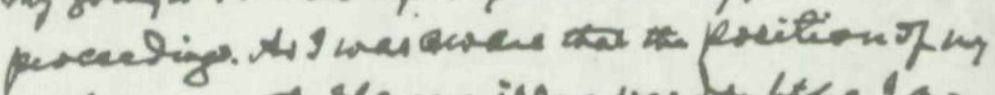

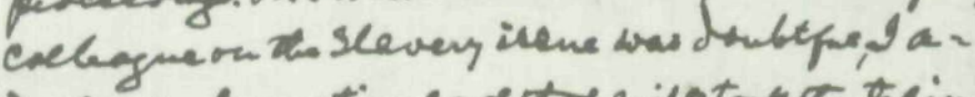

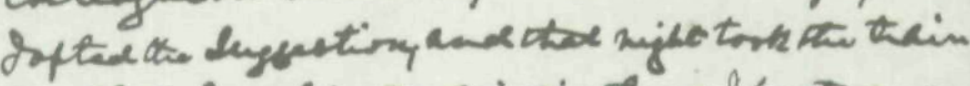
Anothicaleptia. On aviuning theres dunted up

Here is a reproduction of the first page of Clarke's handwritten comments. Courtesy SHSI, Iowa City. 
vention, and was the only person in it from West of the Mississippi River, I then residing in Iowa, at Iowa City. ${ }^{13}$ On the organization of the Convention, Frank P. Blair, Sr. the friend of Gen. [Andrew] Jackson, who then resided in Maryland, was appointed tempor[ar]y Chairman, and myself temporary Secretary, and acted as such the first day. "The National Council" of the American, or "Know-Nothing" party was in session in Philadelphia, at the same time, to which a man named Webster ${ }^{14}$ and myself were delegates from the State of Iowa. After the adjournment of the Pittsburg Convention, on the first day, Horace Greeley ${ }^{15}$ and others, learning that I had a right to a seat in the Know-Nothing body, and that a proslavery platform had been introduced and was then pending, insisted on my going to Philadelphia, and taking part in its proceedings. As I was aware that the position of my colleague on the slavery issue was doubtful, I adopted the suggestion and that night took the train for Philadelphia. On arriving there, I hunted up my colleague, ascertained the status of the platform, and found that he was undetermined as to his vote. I then hunted up Ex-Lieut. Gov. Ford, ${ }^{16}$ of Ohio, with whom I was acquainted, and who stood at the head of the free-soil forces, and after consultation, we determined to call a meeting of our friends that afternoon, to meet at the Commercial Hotel, which we did. This was on Sunday, and that afternoon the meeting was held. We determined to offer a substitute to so much of the platform, which was to [be]

13. Again, Clarke is apparently mistaken, as all of the free states, plus the Kansas, Nebraska, and Minnesota territories, were represented. Easterners often served as representatives for distant states that could not afford to send delegates to far-flung conventions, so it may be that Clarke was the only person residing west of the Mississippi.

14. L. H. Webster, a Cedar Rapids attorney. A third delegate, James Thorington, also represented Iowa at the convention.

15. Horace Greeley was editor of the New York Tribune and an influential figure in the founding of the Republican party. In 1872 Greeley would run for president as the Liberal Republican and Democratic candidate.

16. Thomas H. Ford was still lieutenant governor of Ohio at the time of the Know Nothing convention. He eventually became an active Republican, although he attributed his failure to obtain any significant public offices afterwards to Republican efforts to disassociate themselves from nativism. 
voted on the next morning, as recognized the right of the Southern men to carry their slaves into free territory, \&c. We further agreed that if our substitute was rejected, as we expected it would be, to withdraw in a body from the Council. Ford was a large man, over six feet tall. He was to offer the substitute, and on its rejection, he was to rise, raise his hat, and we were simultaneously to follow his example, and retire from the hall. Ephraim Marsh, of New Jersey, was the president of the Council, and he was in sympathy with the North. ${ }^{17}$ We had an interview with him, and he promised that he would give Ford the floor, in the morning, when the Council convened. With this understanding, we-some sixty of us - went early to the Council, and as soon as the Chaplain had closed his prayer, Ford rose and was recognized. He at once offered our substitute. A five minutes debate followed, in which our friends participated, the Southern men, sitting quiet, and seemingly dumbfounded. They were taken by surprise, but they did not fail to vote, and our substitute was rejected. No sooner was the vote announced, than the tall form of Ford arose amid the excited crowd, and raising his arm its full length, with his hat in his hand, he started for the door, while his followers did the same. ${ }^{18}$ Never was such a scene witnessed, before or since, in a poli[ti]cal assemblage. The pro-slavery men were on their feet, denouncing us as "negro thieves," "abolitionists," "disunionists," with every other opprob[r]ious epithet in their vocabulary. This was the "most wonderful political feat," which in the language of Lamon, which "had been performed," and which, instead of being the work of politicians, resulted from the labors of honest patriotic men, who were determined to preserve the free territory of the nation from the taint and crime of slavery.

17. Marsh was indeed sympathetic to the antislavery forces. After the convention, Marsh's letter repudiating Fillmore's nomination became a favorite Republican campaign document. See Ephraim Marsh, Reasons for Going for Fremont (n.p., 1856); and North American Documents: Letters From Geo. Law, Ephraim Marsh, \& Chauncey Shaffer (n.p., 1856).

18. Actually, the northerners left the hall only after Edmund Perkins of Connecticut delivered a defiant speech explaining why northerners would not remain in the convention if the party did not change its stance on the slavery extension issue. 
And this was the beginning of the "disintegration" of the American Party. ${ }^{19}$

Lamon, on page 378, denounced "the Free Soil politicians," as "for the most part bad, insincere, trading men, with whom the profession of principles of any kind was merely a convenient disguise, and who could be attached to no party except from motives of self-interest." ${ }^{20}$ In this he is entirely mistaken. The original free-soilers were not politicians, or if they were, they at once sacrificed their standing in the parties to which they had belonged. My own case is one in point. I had been an active Whig up to the nomination of Gen. Taylor, on a pro-slavery platform..$^{21}$ But with my hostility to the extension of slavery, I could not support the ticket, and consequently, I was driven into the Free Soil ranks, and I

19. In fact, the beginning of the disintegration of the American party occurred in June 1855, when its previous national convention adopted the platform tacitly endorsing the Kansas-Nebraska Act. Most northern Know Nothings had hoped that the February convention would remove that plank from the party's statement of principles. When the delegates failed to make that change in 1856 , the exodus from the party became irreversible. Thus, Clarke would have been more accurate had he said that the events in Philadelphia had ensured the disintegration of the American party. See Anbinder, Nativism and Slavery, 210-15, 221-38. For the best contemporary accounts of the Philadelphia convention, see the New York Times, 26 February 1856; and William B. Hesseltine and Rex G. Fisher, eds., Trimmers, Trucklers and Temporizers: Notes of Murat Halstead from the Political Conventions of 1856 (Madison, WI, 1961), 1-7.

20. Lamon's words reflected the consensus opinion at the time he published the book in 1872. In that era, historians describing the Free Soil party emphasized the role of Martin Van Buren and his followers, many of whom had joined the organization disingenuously in order to anger the southern Democrats who had denied him the Democratic presidential nomination in 1844. Currently, however, most historians would agree with Clarke that, with the exception of those who joined the party to aid Van Buren's presidential aspiration, most Free Soilers were dedicated to the party's antislavery principles. Only for a short period did Van Buren's supporters divert the organization from its stated goals. See Richard H. Sewell, Ballots for Freedom: Antislavery Politics in the United States, 1837-1860 (New York, 1976).

21. In fact, General Zachary Taylor was not nominated on a proslavery platform by the Whigs in 1848 . Hoping to avoid any action that might anger potential supporters of the war hero, they did not draft a platform at all that year. Clarke is probably referring to the statement of principles adopted by a public ratification meeting held after the convention. The convention's failure to endorse the Wilmot Proviso, combined with the 
stumped the State and voted for Van Buren, as a presidential elector, though I had opposed him all my life; and by this course, I forfeited my political standing and prospects.

Lamon, also, denounced the Know-Nothing Party as "corrupt, hideous, and delusive." In this he also is mistaken. Many joined this party from various motives, other than opposition to foreigners. With many, the object was to divide and disrupt the Democratic party. It was this motive which induced me to become a Know-Nothing. The State of Iowa was intensely democratic, and controlled mainly by Southern men,- the sons or other relatives of Southern members of Congress. They brought their bad principles with them, and they assumed to be the Lords of the Earth. Until this influence could be destroyed, there was no hope for the redemption of the State, and this redemption could only come by interesting the masses of the party in new questions. It was with this view that I joined the Know-Nothings, and it was by junction of this organization, with old Whigs, free-soilers, and other factions, upon the issue of "free men, free soil and free speech," that the State of Iowa was redeemed from the thraldom of pro-slavery Democracy, and was made, and has continued to be, a reliable Republican State.

nearly unanimous support the slaveholder Taylor received from southern delegates, created the impression in some minds that Taylor was a proslavery candidate. See David M. Potter, The Impending Crisis, 1848-1861 (New York, 1976), 81. 
Copyright of Annals of Iowa is the property of State of Iowa, by \& through the State Historical Society of Iowa and its content may not be copied or emailed to multiple sites or posted to a listserv without the copyright holder's express written permission. However, users may print, download, or email articles for individual use. 